\title{
Assessment of Potential Shale-Oil and Shale-Gas Resources in Silurian Shales of Jordan, 2014
}

$\boldsymbol{U}$ sing a geology-based assessment methodology, the U.S. Geological Survey estimated means of 11 million barrels of potential shale-oil and 320 billion cubic feet of shale-gas resources in Silurian shales of Jordan.

\section{Introduction}

The U.S. Geological Survey (USGS) quantitatively assessed the potential for shale-oil and shale-gas resources in the Silurianage source-reservoir rock system of Jordan (fig. 1). This study did not include the potential for oil-shale resources of Jordan, which should not be confused with shale-oil resources. Oil shale is a rock in which the organic matter that is the precursor to oil (kerogen) remains thermally immature and oil has not been generated, whereas shale oil is thermally mature oil that is generated and remains within the source rock. Undiscovered conventional oil and gas resources were assessed in Jordan in 2012 as part of the Middle East region (Pitman and others, 2012).

The tectonic history of Jordan had a significant effect on retention of hydrocarbons generated within the Silurian sourcereservoir rock system. Organic-rich Silurian marine shales in parts of Jordan were thermally mature with respect to oil and gas generation prior to the Hercynian orogeny, which took place from Devonian through Carboniferous time. Uplift and erosion on the order of 2,500 meters $(\mathrm{m})$ or more during this orogeny led to significant risk with respect to retention of oil and gas within the source rock (Skarpnes and Hagen, 2008). Retention risk was a major part of the geologic evaluation prior to the quantitative assessment.

To be considered for a USGS assessment, any sourcereservoir rock system must (1) have greater than 2 weight percent total organic carbon (TOC); (2) be within the proper thermal maturity window for oil or gas generation; (3) have greater than $15 \mathrm{~m}$ of organic-rich shale; (4) contain Type I or II organic matter, and (5) occur at depths greater than 1,500 $\mathrm{m}$ (Charpentier and Cook, 2011). Areas that do not meet these criteria are unlikely to have significant resource potential without major technological improvements or major price increases. Once potential areas for assessment are defined, the tectonic history, thermal history, and timing of maturation and generation are used to evaluate the risk of retention of hydrocarbons within the source rock.

Three assessment units (AUs) were defined in this study. The AUs correspond to areas in Jordan where organic-rich Type II Silurian marine shales are thermally mature for oil or gas, are greater than $15 \mathrm{~m}$ thick, and have greater than 2 weight percent TOC (fig. 1). The Sirhan Area Jordan Silurian Shale Oil AU was defined to encompass potential thermally mature, oil-bearing Silurian shales in the Sirhan area. Uplift and erosion on the

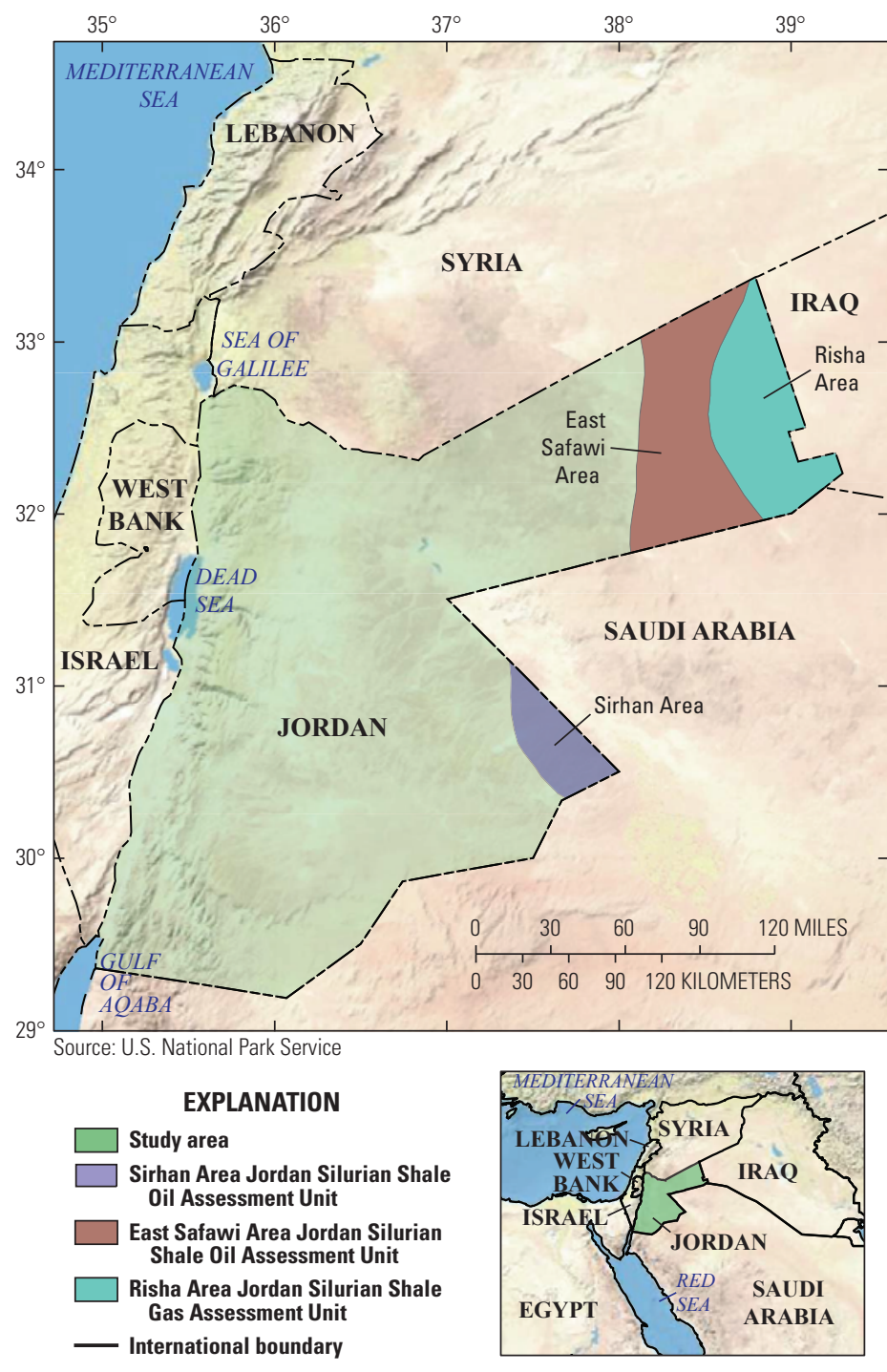

Figure 1. Map showing locations of three areas of Jordan assessed in this study.

order of 2,500 $\mathrm{m}$ or more resulted in most of the shale being less than $1,500 \mathrm{~m}$ deep. The uplift history is interpreted to have significantly reduced the potential for shale-oil resources. The East Safawi Area Jordan Silurian Shale Oil AU defines an area of potential thermally mature oil-bearing shales in northeast Jordan. In this area, uplift resulted in partial erosion of Silurian shales, providing a high risk for retention for oil in the source rock-reservoir system. The Risha Area Jordan Silurian Shale Gas AU was defined to encompass potential gas-bearing Silurian shales in the Risha area. Uplift and erosion in this area was perhaps on the order of $1,200 \mathrm{~m}$, and is interpreted to have had 
less of an effect on gas retention in the source rock compared to the previous areas.

The assessment input data for each unconventional AU are shown in table 1 . Assessment unit probabilities are shown in table 2.

\section{Resource Summary}

The USGS quantitatively assessed unconventional shale-oil and shale-gas resources in three assessment units within Jordan (table 2). For unconventional resources, the mean totals are: 11 million barrels of shale oil (MMBO), with a range from 0 to $45 \mathrm{MMBO} ; 320$ billion cubic feet of shale gas (BCFG), with a range from 0 to $917 \mathrm{BCFG}$; and 25 million barrels of natural gas liquids (MMBNGL), with a range from 0 to 79 MMBNGL.

Of the mean total shale-oil resource of $11 \mathrm{MMBO}, 8 \mathrm{MMBO}$ are estimated to be in the Sirhan Area Jordan Silurian Shale Oil $\mathrm{AU}$, and $3 \mathrm{MMBO}$ are estimated in the East Safawi Area Jordan Silurian Shale Oil AU. Nearly all potential shale-gas resources are in the Risha Area Jordan Silurian Shale Gas AU (mean of 312 $\mathrm{BCFG}$, with a range from 0 to $885 \mathrm{BCFG}$ ). The ranges of resource estimates reflect the high geologic uncertainty on the retention of oil and gas in the Jordanian Silurian source rock-reservoir system.

\section{For Further Information}

Assessment results are available at the USGS Energy Resources Program website, http://energy.usgs.gov/oilgas/.

\section{References Cited}

Charpentier, R.R., and Cook, T.A., 2011, USGS methodology for assessing continuous petroleum resources: U.S. Geological Survey Open-File Report 2011-1167, 75 p., http://pubs.usgs. gov/of/2011/1167/.

Pitman, J.K., Schenk, C.J., Brownfield, M.E., Charpentier, R.R., Cook, T.A., Klett, T.R., Pollastro, R.M., 2012, Assessment of undiscovered conventional oil and gas resources of the Arabian Peninsula and Zagros Fold Belt, 2012: U.S. Geological Survey Fact Sheet 2012-3115, 4 p., http://pubs. usgs.gov/fs/2012/3115/.

Skarpnes, Oddvar, and Hagen, Sveinung, 2008, Sirhan Block evaluation, Jordan-Evaluation Report: Stavanger, Norway, Statoil, 89 p.

Table 1. Key assessment input data for unconventional assessment units in Jordan.

[EUR (estimated ultimate recovery per well), well drainage area, and success ratios are from U.S. shale-gas and shale-oil analogs. MMBO, million barrels of oil; BCFG, billion cubic feet of gas; AU, assessment unit. The average EUR input is the minimum, median, maximum, and calculated mean.]

\begin{tabular}{|c|c|c|c|c|c|c|c|c|}
\hline \multirow[b]{2}{*}{ Assessment input data } & \multicolumn{4}{|c|}{ Sirhan Area Jordan Silurian Shale Oil AU } & \multicolumn{4}{|c|}{ East Safawi Area Jordan Silurian Shale Oil AU } \\
\hline & Minimum & Mode & Maximum & $\begin{array}{c}\text { Calculated } \\
\text { mean }\end{array}$ & Minimum & Mode & Maximum & $\begin{array}{c}\text { Calculated } \\
\text { mean }\end{array}$ \\
\hline Potential production area of AU (acres) & 0 & 29,000 & 290,000 & 106,333 & 0 & 86,000 & 860,000 & 315,333 \\
\hline Average drainage area of wells (acres) & 80 & 160 & 220 & 153 & 80 & 160 & 220 & 153 \\
\hline Success ratios $(\%)$ & 10 & 40 & 70 & 40 & 10 & 40 & 70 & 40 \\
\hline \multirow[t]{3}{*}{ Average EUR (MMBO, oil; BCFG, gas) } & 0.01 & 0.03 & 0.1 & 0.034 & 0.01 & 0.03 & 0.1 & 0.034 \\
\hline & \multicolumn{4}{|c|}{ Risha Area Jordan Silurian Shale Gas AU } & \multirow{6}{*}{\multicolumn{4}{|c|}{$\begin{array}{l}\text { Jordan Assessment Team } \\
\text { Christopher J. Schenk, Janet K. Pitman, } \\
\text { Ronald R. Charpentier, Timothy R. Klett, } \\
\text { Marilyn E. Tennyson, Tracey J. Mercier, } \\
\text { Philip H. Nelson, Michael E. Brownfield, } \\
\text { Mark J. Pawlewicz, and Craig J. Wandrey. }\end{array}$}} \\
\hline & Minimum & Mode & Maximum & $\begin{array}{c}\text { Calculated } \\
\text { mean }\end{array}$ & & & & \\
\hline Potential production area of AU (acres) & 0 & 276,000 & $1,105,000$ & 460,333 & & & & \\
\hline Average drainage area of wells (acres) & 120 & 160 & 200 & 160 & & & & \\
\hline Success ratios $(\%)$ & 10 & 50 & 90 & 50 & & & & \\
\hline Average EUR (MMBO, oil; BCFG, gas) & 0.1 & 0.2 & 1 & 0.24 & & & & \\
\hline
\end{tabular}

Table 2. Jordan shale-oil and shale-gas resource assessment results.

[MMBO, million barrels of oil; BCFG, billion cubic feet of gas; MMBNGL, million barrels of natural gas liquids; TPS, total petroleum system; AUs, assessment units.

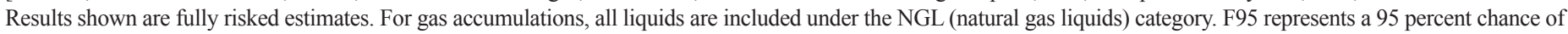

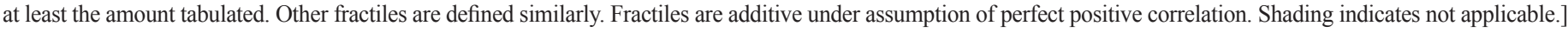

\begin{tabular}{|c|c|c|c|c|c|c|c|c|c|c|c|c|c|c|}
\hline \multirow{3}{*}{$\begin{array}{l}\text { Total Petroleum System } \\
\text { (TPS) } \\
\text { and Assessment Units (AUs) }\end{array}$} & \multirow{3}{*}{$\begin{array}{l}\text { AU } \\
\text { Prob- } \\
\text { ability }\end{array}$} & \multirow{3}{*}{$\begin{array}{c}\text { Accu- } \\
\text { mulation } \\
\text { Type }\end{array}$} & \multicolumn{12}{|c|}{ Total Undiscovered Resources } \\
\hline & & & \multicolumn{4}{|c|}{ Oil (MMBO) } & \multicolumn{4}{|c|}{ Gas (BCFG) } & \multicolumn{4}{|c|}{ NGL (MMBNGL) } \\
\hline & & & F95 & F50 & F5 & Mean & F95 & F50 & F5 & Mean & F95 & F50 & F5 & Mean \\
\hline \multicolumn{15}{|c|}{ Silurian TPS } \\
\hline $\begin{array}{l}\text { Sirhan Area Jordan Silurian } \\
\text { Shale Oil AU (20260161) }\end{array}$ & 0.9 & Oil & 0 & 6 & 24 & 8 & 0 & 4 & 18 & 6 & 0 & 0 & 0 & 0 \\
\hline $\begin{array}{l}\text { East Safawi Area Jordan Silurian } \\
\text { Shale Oil AU (20290161) }\end{array}$ & 0.1 & Oil & 0 & 0 & 21 & 3 & 0 & 0 & 14 & 2 & 0 & 0 & 0 & 0 \\
\hline $\begin{array}{l}\text { Risha Area Jordan Silurian } \\
\text { Shale Gas AU (20290162) }\end{array}$ & 0.9 & Gas & & & & & 0 & 235 & 885 & 312 & 0 & 17 & 79 & 25 \\
\hline Total unconventional resources & & & 0 & 6 & 45 & 11 & 0 & 239 & 917 & 320 & 0 & 17 & 79 & 25 \\
\hline
\end{tabular}

